\title{
Piotr Borowski*
}

\section{Głos praktyka w sprawie kształcenia dziennikarzy}

\section{Szanowni Państwo!}

$\mathrm{Na}$ wstępnie chciałbym serdecznie Państwu pogratulować z okazji jubileuszu. To wprawdzie dopiero 10 lat, ale widać, jak bardzo potrzebnych dla rozwoju środowiska dziennikarskiego w Łodzi. Na szczególne uznanie zasługuje Państwa otwartość na współpracę z łódzkimi redakcjami. Mogę to ocenić na własnym przykładzie.

Od kilku lat w redakcji TVN24 w Łodzi pojawiają się studenci dziennikarstwa z Uniwersytetu Łódzkiego. Przychodzą zazwyczaj w ramach praktyk i staży. Moim zdaniem, nie ma lepszej formy zdobywania warsztatu dziennikarskiego niż właśnie tego typu aktywności. Młodzi ludzie uczą się dziennikarstwa pod okiem doświadczonych pracowników, widzą, jak wygląda praca reportera, a następnie sami stawiają pierwsze kroki w tym fachu. Muszę przyznać, że ilekroć w naszej redakcji słyszymy, iż przyszedł do nas student dziennikarstwa UŁ, to jesteśmy spokojni o jego przygotowanie merytoryczne. W TVN24 mogą swoją wiedzę zaprezentować w praktyce, jednocześnie nadal ucząc się i zdobywając doświadczenie - tak ważne w tym zawodzie.

Pragnę zauważyć, że kilkoro studentów pozostawiło po sobie na tyle dobre wrażenie, iż otrzymali oni ofertę płatnej współpracy. Młody człowiek, który może spełniać swoje marzenia o byciu dziennikarzem i dodatkowo otrzymuje pieniądze, może odczuwać - proszę mi wierzyć - olbrzymią satysfakcję z takiego początku kariery. Wierzę, że jest to z korzyścią dla wielu stron: dla studentów, bo zdobywają doświadczenie, dla naszej redakcji, bo mamy młodych i ambitnych ludzi do pracy, oraz dla Uniwersytetu, bo jego studenci poszerzają wiedzę i mają możliwość zaistnienia na rynku pracy.

Dziękując za tak owocną współpracę w ostatnich latach, chciałbym jednocześnie zwrócić się do Państwa $\mathrm{z}$ apelem, a zarazem prośbą. Kiedy sam studiowałem dziennikarstwo, moi nauczyciele - doświadczeni dziennikarze - wielokrotnie wpajali mi i innym studentom następujące zasady:

\footnotetext{
* Mgr, TVN Łódź, e-mail: p.borowski@tvn.pl.
} 
- Dziennikarz musi być niezależny.

- Dziennikarz musi być obiektywny.

- Dziennikarz musi mówić prawdę.

Banały? Niekoniecznie. Obecnie wielu dziennikarzy staje się narzędziem w rękach polityków. Często goszczą w mediach informacje nieprawdziwe i zmanipulowane. Dlatego musimy zdawać sobie sprawę, jak ważne - zwłaszcza dziś - jest przyswojenie tych zasad przez adeptów dziennikarstwa.

To także apel do Państwa, by podczas kształtowania postaw przyszłych dziennikarzy mieć na uwadze przypominanie o tych podstawowych zasadach etycznych i moralnych. Bez niezależności, obiektywizmu i rzetelności nie ma dziennikarstwa. Wierzę, że absolwenci Uniwersytetu Łódzkiego zawsze będą kierować się tymi wartościami. 